\title{
Exchange rate pass-through in the deflationary Japan: How effective is the yen's depreciation for fighting deflation?
}

\author{
Eiji Fujii \\ Institute of Policy and Planning Sciences \\ University of Tsukuba
}

\begin{abstract}
There is an increasing endorsement for the yen's depreciation as a means to fight the ongoing deflation in Japan. The idea of generating inflation via depreciation relies on the assumption that exporters pass-through most of the effect of the exchange rate changes to the Japanese importers and consumers. A recent study by Taylor (2000), however, suggests that the rate of the pass-through may have declined in many countries making depreciation of domestic currencies less inflationary. In this study, we estimate the degree of exchange rate pass-through to the Japanese imports, focusing on the recent deflationary period. We then assess quantitatively the expected effectiveness of depreciation in taming the deflation. Our empirical results indicate that the long-run import pass-through has indeed declined significantly. As a result, the inflationary effect of depreciation has been reduced substantially over the past two decades.
\end{abstract}

JEL Classification: E31, F30, F40

Keywords: pass-through, exchange rate, deflation, Japan

Acknowledgements: An earlier draft of this paper was presented at the CESifo 2003 Venice Summer Institute "Economic Stagnation in Japan”. I am grateful to Takatoshi Ito and Fukunari Kimura for invaluable comments and discussion. I also thank Jeannine Bailliu, Yin-Wong Cheung, Menzie Chinn, Jenny Corbett, Reuven Glick, Charles Yuji Horioka, Ken Kletzer, Joe Peek, Shigenori Shiratsuka, and participants of the VSI for helpful comments. All remaining errors are solely mine.

Address for correspondence: Eiji Fujii, Institute of Policy and Planning Sciences, University of Tsukuba, Tennodai 1-1-1, Tsukuba, Ibaraki 305-8573, Japan. Ph. / Fax: +81 298535176. E-mail: efujii@sk.tsukuba.ac.jp. 


\section{Introduction}

Deflation seems inexorable in the ailing Japanese economy. After years of stagnation there is now a symptom that the world's second largest economy is being trapped in a vicious cycle of output contraction and price decline. As the economy continues to languish, it is more urgent than ever before to create an upward pressure on prices to put an end to the ongoing deflation. Economists, policy makers, and politicians have been debating on how to do it. Many agree on the devastating effect of the enduring deflation and the urgency of effective policy action to address the problem. Nevertheless, they disagree strongly with each other on what to be done in concrete terms. As the economic slump prolongs, a number of people have come forward to advocate for non-conventional measures such as adoption of inflation targeting by the Bank of Japan (BOJ). The call for aggressive measures, however, has been tenaciously disputed by those who opt for more conventional measures.

In the current debate over how to fight the deflation, there is an increasing endorsement for the yen's depreciation as a means to generate a significant inflationary pressure in the economy. News media report eminent economists and policy makers in Japan endorsing so-called "yenyasu-yudo", meaning active inducement of the yen's depreciation, for the purpose of creating an upward price pressure via import inflation. ${ }^{1}$ Calls for depreciating the currency come also from international economists, such as Svensson (2003), as part of policy recommendations on how to pull the economy out of

\footnotetext{
${ }^{1}$ For instance, according to the Nikkei Shimbun (February 22, 2003), at the meeting hosted by the Policy Research Institute of the Ministry of Finance, Hiroshi Yoshikawa, a member of the Council on Economic and Fiscal Policy of the Cabinet Office and the former Vice Minister of Finance Haruhiko Kuroda agreed on that a depreciation to 130-140 yen per dollar level will have an immediate and significant effect on the deflation by raising the import price. The yen/dollar rate then was 118.90 , so the suggested depreciation is by approximately 9 to 18 percent. The media also reports that a similar view to support "yenyasu-yudo" has been expressed at the Monetary Policy Meeting of the BOJ by some of its constituents.
} 
a liquidity trap. ${ }^{2}$ Given the persistence of the downward movements in the domestic prices, it is not surprising that an increasing amount of attention is directed to potential roles of a currency depreciation and import inflation as an instrument for alleviating the situation.

While the idea of spurring inflation via depreciation may sound straightforward, it implicitly assumes a condition that remains controversial in international economics. ${ }^{3}$ Specifically, it presupposes that foreign producers stabilize the prices of their exports to Japan in their own currency terms, and hence, pass the effects of the yen's depreciation substantially, if not fully, to the Japanese importers and consumers. ${ }^{4}$

In this paper, we examine empirical validity of the above-mentioned assumption specifically in the recent Japanese environment where domestic prices exhibit a clear downward trend. We do so by estimating exchange rate pass-through (ERPT) to the Japanese import prices and quantifying its effects on overall domestic inflation. The objective is to assess quantitatively the expected effectiveness of the proposed measure to tame the deflation by actively weakening the yen. ${ }^{5}$

Our investigation of ERPT specifically for the recent deflationary Japan is

\footnotetext{
2 Svensson (2003) suggests a substantial depreciation and a temporary crawling peg as a devise to escape from a liquidity trap and deflation. Although import inflation is not the primary focus in his recommendation, he refers to it as a "direct channel" and notes its desirable effects.

${ }^{3}$ More fundamentally, it is questionable if the BOJ can actively drive the exchange rate to a desired level. While effectiveness of market intervention remains controversial in general, it is even more so in the current scenario because (i) Japan has no room to reduce its interest rates, (ii) a massive-scale sale of the domestic assets can have a serious negative impact on the economy, and (iii) the U.S. and the E.U. do not appear particularly enthusiastic about cooperative interventions. However, we assume that the BOJ is capable of at least inducing depreciation, if not depreciation by a desired amount, and ask how effective it would be in terms of reversing the downward trend of domestic prices.

${ }^{4}$ Another implicit assumption is that movements of import price have sizable effects on Japan's overall inflation.

5 The yen's depreciation is expected to have also an export-boosting effect that partially makes up for the frail domestic demand. This is one reason that the proposal for weaker yen is gaining popularity. In this paper, however, we limit our scope to its effects on the domestic inflation.
} 
motivated primarily by an intriguing hypothesis put forward by Taylor (2000). In analyzing the relationship between firms' pricing behavior and inflation environment, Taylor (2000) contends that pass-through has declined substantially in many countries as a consequence of successful transitions to low inflation regimes. If valid, Taylor's conjecture has an important implication for the current policy debate in Japan. Specifically, it implies that the yen's depreciation can be substantially less inflationary now than it was in the past. If so, the proposed measure of combating deflation via depreciation can be significantly less effective than what its advocates may have in mind. It is, therefore, important to carefully quantify the responsiveness of the Japanese import and overall prices to exchange rate fluctuations in the recent deflationary environment.

The remainder of this manuscript is organized in the following manner. Section II discusses Taylor's conjecture on ERPT and domestic inflation and how it relates to the current Japanese environment. Section III describes the data. An empirical model of ERPT is presented in section IV. In section V, we estimate ERPT to the Japanese imports using disaggregated price indexes. Then, we examine whether or not the degrees of the pass-through in the recent deflationary period differ from those in prior periods. An empirical investigation is extended in section VI, where we adopt alternative data with a finer level of disaggregation by industry to obtain pass-through estimates for the most recent period. After quantifying the expected inflationary effects of the yen's depreciation, we provide concluding remarks in section VII.

\section{Exchange rate pass-through and domestic inflation environment}

When the yen depreciates against the currencies of major exporters to Japan, 
prices of the Japanese imports can rise in general, which in turn, may spur overall inflation. However, the import price does not necessarily rise at the same rate as the yen depreciates. The degree of the yen price responsiveness may be anywhere from zero to $100 \%$, depending on how much of the exchange rate change the exporting firms decide to absorb or shift to the Japanese importers and consumers.

To illustrate the point, consider an imperfectly competitive foreign firm exporting its product to the Japanese market while facing competition from the Japanese domestic producers. As a price setter, the firm solves the following profit maximization problem:

$$
\max _{p} \pi=s^{-1} p q\left(p, p^{d}, y\right)-C\left(q(.), w^{*}\right)
$$

where $s$ is the exchange rate measured by units of the yen per unit of the exporter's currency, $p$ is the import price of the product in yen, and $q($.$) is the demand for the$ product that depends not only on own price but also on the price of the domestic competing product $p^{d}$ and the income level $y$. The production cost $C($.$) is$ determined by the level of the demand for the product and the input price $w^{*}$ measured in the exporter's currency units.

Solving (1) yields the following first order condition:

$$
p=s C_{q} \mu
$$

where $\mu \equiv \eta /(\eta-1)$ and $\eta$ is the demand elasticity of the product that depends on its relative price to the competing domestic product. With all terms converted into logarithms, the effect of exchange rate change on the import price (in yen) is:

$$
\frac{\partial p}{\partial s}=1+\frac{\partial C_{q}}{\partial s}+\frac{\partial \mu}{\partial s}
$$

It is important to note that the marginal cost $C_{q}$ and the markup ratio $\mu$ depend also 
on other factors than the exchange rate. In other words, when estimating ERPT, $\partial p / \partial s$, it is crucial to control for $w^{*}, y$, and $p^{d}$.

Equation (3) suggests that full pass-through is a special case where neither the marginal cost nor the markup is altered in the face of exchange rate fluctuations. ${ }^{6}$ In general, the degree of ERPT depends crucially on the behavior of the marginal cost and markup, which are likely to be specific to the exporting firm and/or industry. Consequently, the literature has treated ERPT primarily as a microeconomic phenomenon. ${ }^{7}$ Recently, however, Taylor (2000) has brought an explicit macroeconomic perspective to the issue using a staggered price-setting model. Specifically, the model posits that firms set prices of their products at different points in time and keep them unaltered for four periods. Thus, in deciding own prices firms maximize their expected profit for the next four periods based on their expectations about future movements of other firms' prices, own production cost, and the market demand. In discussing how projected changes to these variables affect firms' decision, Taylor points out that the price response will be greater if the changes are perceived to be more permanent. In relating the perceived persistence of changes to the competing product prices to the persistence of general inflation, he argues that the effective control over inflation established in recent years has resulted in a decline in the pricing power of firms in many countries. ${ }^{8}$

Taylor's conjecture has a significant ramification on the current policy debate

\footnotetext{
6 The other possibility is the case where the marginal cost and the markup moves by the same amount but in the opposite directions.

7 In particular, the nature of market competition and the cost structure have been examined as a determinant of ERPT. See, for instance, Dornbusch (1987), Feenstra (1989), Goldberg and Knetter (1997), and Yang (1997).

8 Similarly, increase in (perceived) persistence in exchange rate changes leads to a greater price response by a firm. See Taylor (2000) for further details.
} 
over deflation in Japan. To describe the Japanese situation, Figure 1 depicts Japan's domestic and overall wholesale price indexes in logarithms since 1973:3. ${ }^{9}$ The price indexes exhibit a very steep upward trend through the 1970s. However, they more or less flatten out in the first half of the 1980s. Entering the 1990s, the price indexes show a gradual but consistent decline except for a few occasional and short-lived upward shifts. To portray the domestic inflation environment further, we provide some descriptive statistics for alternative sample periods in the upper panel of Table 1. As seen in the first column, the average wholesale inflation in Japan, that reached $0.7 \%$ per month in the 1970s, turned negative in the second half of the 1980s and has remained so since then. ${ }^{10}$ In a corresponding fashion, the inflation variability decreased substantially as the sample variances denote. Even more noteworthy is an unequivocal reduction of the inflation persistence reported in the last column. The reported persistence figures denote the estimated half-life in months of the wholesale inflation process using the first order autoregressive coefficient. ${ }^{11}$ The magnitude of the decline is astonishing. The inflation persistence has been reduced from 3.8 months in the 1970 s to just 0.3 month by the second half of the 1990s. Overall, it is unambiguous that the Japanese inflation environment has experienced a substantial transformation, in particular a remarkable reduction of its persistence.

The lower panel of Table 1 summarizes similarly the descriptive statistics for monthly changes in the logged nominal effective exchange rate of the yen. ${ }^{12}$ The consistently negative value of the average exchange rate change reflects the secular

\footnotetext{
9 The indexes are normalized to be one in 1973:3.

${ }^{10}$ In this paper, inflation is measured in terms of a non-annualized monthly rate.

11 The wholesale inflation process is modeled as a first order autoregressive process, and the coefficient estimate is used to calculate its half-life.

12 The exchange rate is measured in units of yen per unit of the foreign currency.
} 
appreciation of the yen through the first half of the 1990s, which is envisaged by Figure 2. A cross-panel comparison of the reported sample variances and coefficient of variations corroborate that the exchange rate change is much more volatile than the inflation. However, it is important to note that, unlike the inflation case, there is no indication for the volatility or the persistence of the yen's effective exchange rate to be shrinking over time.

The overview of the inflation and exchange rate data suggests that Japan makes a good case to testify empirically whether or not the pass-through has declined as the inflation environment shifted, as argued by Taylor (2000). For the current policy debate in Japan, empirical evidence on the issue will provide imperative information regarding the effectiveness of the yen's depreciation as a means to generate inflation pressure. If the import pass-through has indeed been declining, the inflation-spurring effect of the yen's depreciation is also likely to be weakening. Under the circumstances, the efficacy of the "yenyasu-yudo" will be inhibited.

There are numerous previous studies on the Japanese ERPT and a closely related subject matter of pricing-to-market. Many of them, however, investigate the responses of Japanese export prices, rather than import prices, to the exchange rate movements. ${ }^{13}$ In contrast, there are relative few studies that focus on the relationship between the Japanese import price and exchange rate fluctuations. Sazanami, Kimura, and Kawai (1997) examine the movements of both import and export prices of numerous tradable goods, during the 1985-1995 period of the yen's steady appreciation. For a large number of products, these authors find that the import price did not decline as much as the yen appreciated. A recent paper by Otani, Shiratsuka, and Shirota (2003)

\footnotetext{
13 See, for instance, Gagnon and Knetter (1995), Giovannini (1988), Marston (1990), and Ohno (1989) for analyses on the Japanese exporting firms’ pricing behavior.
} 
examines stability of the Japanese import pass-through using disaggregated import price indexes for eight product categories for 1978-2002. These authors report that, contrary to the finding of a multi-country analysis by Campa and Goldberg (2002), shifts in import composition over time are not a primary factor for instability of Japan’s import pass-through.

Aside from the studies on Japan, Hooper and Mann (1989) is an important predecessor that examines the stability of the US import pass-through. In examining price movements of manufacture goods, they find little evidence against stability of the pass-through coefficients in the 1980s. Since Taylor (2000) put forth his view, the literature has seen a rejuvenated interest in stability of ERPT. Recent studies addressing the issue include Campa and Goldberg (2002), Choudhri and Hakura (2001), Gagnon and Ihrig (2001), and McCarthy (1999). The empirical evidence reported in these studies is mixed, and thus, the declining pass-through remains a proposition rather than an indisputable fact.

\section{Data description}

We examine responses of imported product prices to exchange rate movements in Japan, especially in the recent deflationary era, using two different panels of disaggregated wholesale price index data. ${ }^{14}$ The first panel contains the price indexes on imported and domestic products, respectively, that are disaggregated by stage of use and demand. The product categories consist of raw materials (raw materials for processing;

\footnotetext{
14 Price responses at the retail level may be a better indicator of overall effects of depreciation since they also reflect movements of additional price markups by domestic distributors and retailers. However, with consumer price indexes, we are unable to separate changes in import prices from those in domestic prices. Also, the wholesale price data allows us to quantify ERPT to imported input prices, which is consistent with Taylor's theoretical framework. For these reasons, we choose to work with the wholesale price index data.
} 
construction materials; fuel), intermediate inputs (semi-finished goods; construction materials; fuel and energy; other intermediate materials), and final goods (capital goods; consumer durables; consumer non-durables). ${ }^{15}$ The panel spans the post-Bretton Woods period (1973:3-2001:12), and thus, it enables us to contrast ERPT estimates under alternative inflation environments such as the high inflation era of the 1970s to the early 1980s and the more recent deflationary circumstances. ${ }^{16}$ Another merit of the panel is that it allows us to compare the degrees of ERPT at different stages of goods production by separating the price indexes of raw materials, intermediates, and finished goods from each other. This form of data disaggregation enables us to study the hypothesized decline of the firms' pricing power as a universal phenomenon across all stages of goods production.

The second panel contains shorter time series of import and domestic product price indexes but with a finer level of disaggregation by industry. The price indexes are available for sixteen manufacturing sectors, two agricultural, forestry, and fishery sectors, one mining sector, and one scrap and waste sector. ${ }^{17}$ As the microeconomic factors related to the industry market structure are known to be important determinants of ERPT, use of the by-sector data should help increase the accuracy of estimations. ${ }^{18}$ However, the data starts only in 1995, and thus no direct reference can be made to preceding periods of more inflationary environments.

All data are in a monthly frequency and are extracted from the Bank of Japan

\footnotetext{
15 See the appendix for details.

16 While the series goes further back to the 1960s at the source, we utilize only the Post-Bretton Woods period so as to control for potential effects of alternative exchange rate regimes. Also, note that our primary focus is on Japan's experience in the recent deflationary period.

17 All sectors in the wholesale price index are covered. See data appendix for a detailed description of the sectors.

18 Relevant factors include demand elasticity and production cost structure. See Feenstra (1989), Giovannini (1988), Marston (1990), and Yang (1997) among others.
} 
Financial and Economic Data (the 2002 version). The price data include the wholesale price indexes for imported products, domestic products, and overall products, respectively. In addition, we use the data on the trade-weighted nominal and real effective exchange rates, and the industrial production index. We emphasize the necessity of price index data of imported and domestic products in separation. According to (2) and (3), exporting firms' decision should depend on the price of domestic competing products as well as the exchange rate. Without controlling for the movements of domestic competitors' price, the ERPT estimates are likely to be biased. By exploiting the fact that the BOJ report the price indexes of domestic and imported products in separation, we are able to control for the effect to enhance the accuracy of ERPT estimation.

\section{Empirical model specification}

The pricing model of exporting firms described by (2) suggests an empirical specification of the logged import price:

$$
p_{t}=c+\phi(L) p_{t-1}+\lambda(L) s_{t}+\delta p_{t}^{d}+\tau w_{t}^{*}+\varphi y_{t}+\varepsilon_{t}
$$

where $c$ is a constant, $p_{t}$ is the import price index of a given product, $s_{t}$ is the nominal effective exchange rate in units of yen per unit of the foreign currency, $p_{t}^{d}$ is

the price index of the competing domestic product, $w_{t}^{*}$ and $y_{t}$ are control variables for the exporter's cost shifter and the importer's demand conditions, respectively, and $\varepsilon_{t}$ is a disturbance term. All variables are in logarithms, and $\phi(L)$ and $\lambda(L)$ are lag polynomials. The lagged import and domestic prices are included as regressors to account for price inertia and to capture, at least in part, expectations for future price 
movements. The lagged exchange rate terms are also allowed since responses of import prices to exchange rate changes may not be fully manifested instantaneously.

As underlined by (2) and (3), in estimating ERPT it is necessary to isolate the exchange rate effect from a few other effects: the exporter's cost shifter, importer's demand conditions, and the price of the domestic competitor. Controlling for additional effects is considered critical, especially for Japan in recent years, where the domestic prices have been declining and the demand condition has been rather weak. Since both of the data panels report the price indexes of imports and domestic products separately, $p_{t}^{d}$ is directly observed. Movements of the exporters' cost are harder to measure, and we resort to constructing a proxy variable. Specifically, we adopt the wholesale price movements of Japan's major trade partners derived implicitly from the nominal and real effective exchange rate series:

$$
w_{t}^{*}=q_{t}-s_{t}+\tilde{p}_{t}
$$

where $q_{t}$ is the real effective exchange rate, and $\tilde{p}_{t}$ is Japan's overall wholesale price index. Finally, to capture the domestic demand conditions, we employ the Japanese industrial production index as $y_{t}$.

To avoid well-known problems in statistical inferences associated with non-stationary variables, we specify the equation in terms of first differences of the logged variables: ${ }^{19}$

\footnotetext{
19 The augmented Dickey-Fuller test results suggest that the series, except for some of the domestic product prices, contain a unit root. Since the domestic price series yield mixed results, we also estimated (6) while replacing $\Delta p_{t-i}^{d}$ with $p_{t-i}^{d}$. The results are similar, and do not alter the story significantly. Assuming non-stationarity of the variables, we also test for cointegration between $p_{t}$ and $s_{t}$. The evidence is generally insignificant, and hence, an error correction term is not included in (6).
} 


$$
\Delta p_{t}=c+\sum_{i=1}^{j} \phi_{i} \Delta p_{t-i}+\sum_{i=0}^{k} \lambda_{i} \Delta s_{t-i}+\delta \Delta p_{t}^{d}+\tau \Delta w_{t}+\varphi \Delta y_{t}+\varepsilon_{t}
$$

for which the lag orders $j$ and $k$ are determined by Akaike information criteria. ${ }^{20}$ In estimating (6), $\Delta p_{t}^{d}$ needs to be treated as an endogenous regressor since the domestic firms compete against the exporting firm taking $\Delta p_{t}$ into account. Therefore, we adopt the instrumental variable technique using lagged domestic product prices as instruments. $^{21}$

The coefficient $\hat{\lambda}_{0}$ gauges the instantaneous effect of exchange rate changes on import inflation. ${ }^{22}$ Prices of goods can be rigid, however, and the effects of exchange rate fluctuations are not necessarily translated into the local prices in an immediate fashion. This is a valid concern particularly for the current study since our data are observed in a monthly frequency. Given the price dynamics of (6), the total effects of exchange rate movements on the import inflation can be gauged by $\sum_{i=0}^{k} \hat{\lambda}_{i} /\left(1-\sum_{i=1}^{j} \hat{\phi}_{i}\right)$. For the remainder of this study, we refer to $\hat{\lambda}_{0}$ and $\sum_{i=0}^{k} \hat{\lambda}_{i} /\left(1-\sum_{i=1}^{j} \hat{\phi}_{i}\right)$ as short-run ERPT and long-run ERPT, respectively.

Unfortunately, the perceived persistence Taylor (2000) refers to is not directly observable, and thus, it is not easily incorporated into the model specification in an explicit fashion. In what follows, we take an indirect approach of estimating the short-run and long-run ERPT for different sample periods, and then to contrast the

\footnotetext{
20 We check the serial correlations in the resulting residuals to ensure the adequacy of the specifications selected by the information criteria.

${ }^{21}$ First through sixth lags of the domestic product price series and a linear trend are used as instruments.

22 The inclusion of the contemporaneous exchange rate term on the right hand side may raise some concerns about endogeneity. However, the use of disaggregated price data enables us to avoid the potential problem given that no single sector is large enough to drive the exchange rate movements by itself.
} 
obtained pass-through coefficients across periods under alternative inflation environments. If Taylor's supposition is right, the pass-through estimates should exhibit a decline in magnitude as we move from a highly persistent inflationary era to a less persistent deflationary period.

\section{Empirical results: By-stage-of-use-and-demand estimates}

Tables 2 and 3 report the estimated short-run and long-run pass-through coefficients using the first panel of price index data that categorizes products by stage of use and demand. For each product category in both tables, the entries in the first column denote the full sample estimates of ERPT. The next five columns contain the sub-sample estimates for 1973:3-1979:12, 1980:1-1984:12, 1985:1-1989:12, 1990:1-1994:12, and 1995:1-2001:12.

To infer the current degree of ERPT in Japan, it would be pertinent to refer to the 1995:1-2001:12 estimates. However, the 1997 Asian crisis exerted a significant effect on the import prices from neighboring economies, which may have altered the Japanese inflation environment considerably. To take into account this possibility, we provide additional estimates in the last column using only the 1997:7-2001:12 data.

Starting with the short-run ERPT in Table 2, the full sample estimates show that exchange rate changes exert significant and immediate effects on the imported product price movements at all stages. The pass-through coefficients are, however, significantly less than unity suggesting that only part of the exchange rate changes are passed instantaneously to the import prices. In comparing the estimates in Panels A, B, and $\mathrm{C}$ of the table, we find no clear pattern of difference in the short-run ERPT among raw materials, intermediate materials, and final goods. 
In contrasting the estimates across sub-periods, we observe that the short-run pass-through is reasonably stable for some product categories while rather unstable for others. For instance, the estimates for consumer non-durable goods are largely stable across periods. On the other hand, the coefficients for construction materials (under both raw materials and intermediate materials) and fuel and energy appear to be decreasing over time. There is yet another group including fuel and capital goods of which short-run ERPT has been increasing over time. It is noted, however, that these mixed results should not be interpreted as evidence for or against declining pass-through since the short-run coefficients represent only part of the overall effects that are more pertinent to Taylor's insight.

The coefficient estimates in the last two columns in Table 2 provide us with an idea on the magnitude of the immediate effect of the yen's depreciation in terms of import inflation. The magnitude of instantaneous inflation ranges from zero (for fuel and energy) to $70-80 \%$ of the depreciation rate (fuel under the raw materials), having many product categories between $45 \%$ and $60 \%$ of the depreciation rate.

To account for the full effect of exchange rate changes on import prices, we now turn to the long-run ERPT estimates in Table 3. As an overall observation, the full -sample estimates reveal that the effects of exchange rate movements on import prices are magnified as the lagged price adjustments are being completed. ${ }^{23}$ For raw materials for processing, fuel, and fuel and energy, the pass-through coefficients are statistically indistinguishable from unity, suggesting that effects of exchange rate changes are completely passed through to the import prices over time. That is, the import price of these products will rise sooner or later at the same rate as the yen's depreciation.

\footnotetext{
23 This is observed by comparing the long-run coefficients with the corresponding short- run coefficients in Table 2.
} 
Comparing the coefficient estimates across sub-periods, however, we find long-run ERPT declining in numerous product categories. Full pass-through is a phenomenon mostly of the 1970s and the 1980s. By the second half of the 1990s, there is no full pass-through observed for any product category. In seven product categories out of ten, the long-run pass-through coefficients in the 1990s are substantially smaller than those for the 1973:3-1979:12 and/or 1980:1-1984:12 samples. In particular, for all three raw material categories the long-run pass-through, which was virtually $100 \%$ in the 1970s and/or the early 1980s, has been reduced substantially to a range of zero to $68 \%$. Similarly, the long-run pass-through has declined substantially for construction materials, and fuel and energy of intermediate materials as well as for capital goods and consumer non-durables of final goods.

The most recent estimates in the last two columns suggest that exporting firms of final goods maintain a relatively high degree of long-run pass-through even in the recent deflationary periods as compared to those of raw materials and intermediates. Since the onset of the Asian crisis, the final goods exporters to Japan have managed to pass $55 \%$ to $65 \%$ of the exchange rate changes to the importers and consumers. We conjecture that a high degree of product differentiation generally associated with final goods may be part of the reason for the maintained pricing power by exporters.

Overall, the empirical results obtained thus far are largely consistent with Taylor's conjecture. As the Japanese economy left the high inflation periods of the 1970s to the early 1980s and entered the deflationary 1990s, the inflation persistence has been reduced and the degree of long-run ERPT has declined in many product categories. In other words, for many products the yen's depreciation in recent years is not as inflationary as it was in the 1970s and the early 1980s. To elaborate on this point 
further, we calculate the effects of a $1 \%$ depreciation of the yen on the overall wholesale inflation using the estimated ERPT coefficients and the weights assigned to each product category in the overall wholesale price index. ${ }^{24}$

The results are reported in Panel A of Table $5 .{ }^{25}$ The reported figures represent overall wholesale price inflation in percentage terms caused solely by import inflation as a result of a one percent depreciation of the yen. ${ }^{26}$ From the figures, it is unambiguous that the long-run inflationary effects of the yen's depreciation have been weakened over time. In fact, the scale of its decline is striking. In the first half of the 1980s, a $1 \%$ depreciation led to $0.092 \%$ inflation of the overall Japanese wholesale price. Depreciation of the same scale, however, generated only $0.065 \%$ inflation in the second half of the same decade. The effect declines further to $0.047 \%$ in the first half of the 1990s. In the most recent periods, the estimates turn out to be only slightly more than $0.050 \%$. Overall, we find that the long-run inflationary effect of the yen's depreciation has been reduced in its magnitude by $40 \%$ to $45 \%$ as compared to what it was in the early 1980s.

The calculated short-run effect is probably somewhat more comforting to the proponents of "yenyasu-yudo" since decline is not obvious. The calculation based on the 1995:1-2001:12 data suggest that a 1\% depreciation would generate an immediate inflation of $0.069 \%$. The corresponding figure for 1980:1-1984:12 and 1985:1-989:12 are $0.063 \%$ and $0.074 \%$, respectively. When we constrain the sample to the post-Asian crisis period, however, the inflationary effects, both short-run and long-run, appear

\footnotetext{
24 Table A.1 in the appendix contains the weights assigned to each category at the data source.

25 The sub-sample calculations for 1973:3-1979:12 are not available since some price indexes start only from 1980:1.

26 In the calculation, we assume that the prices of domestic products (for domestic consumption) stay constant following the depreciation.
} 
substantially weaker. In this latest period, the short-run effect is estimated to be $0.056 \%$, indicating a reduction in its magnitude by $11 \%$ and $24 \%$ from the first and second halves of the 1980s, respectively.

\section{Alternative estimates by industry}

The long-run results in the previous section suggest that a $1 \%$ depreciation should translate eventually to an overall inflation of only about $0.05 \%$. While the results are indicative of a decline in the inflationary effects of yen's depreciation, the calculation is based on the price indexes that are coarsely disaggregated by stage of use and demand. In this section, we exploit the second panel of price index data to obtain ERPT estimates for the most recent periods by finer industry categories. The purpose of this exercise is to supplement the results of the previous section by providing alternative pass-through estimates for the most recent period.

Table 4 summarizes the estimation results. Since the by-industry price index data are available only from 1995:1, the full sample is defined 1995:1-2001:12. In addition to the full-sample estimates, we provide estimates using only the 1997:7-2001:12 data. The first two columns contain full-sample estimates. The short-run coefficients in the first column show that the import prices of all sectors respond to exchange rate changes significantly and immediately. For non-ferrous metals, other manufacturing industry products, inedible agricultural and forestry products, and forestry products (under mining products), the short-run pass-through is complete. This result seems reasonable since some of these sectors are heavily import-reliant, and thus, the exporters tend to face a fairly inelastic demand in Japan. In contrast, the iron and steel sector has the lowest short-run pass-through rate of 0.172 . The sector is associated 
mainly with a low level of product differentiation and dominant presence of Japanese domestic firms, which can constrain exporting firms’ pricing power.

The long-run ERPT estimates are reported in the second column. Generally, more of the exchange rate changes are passed-through to import prices as the price adjustment processes are completed. For instance, the rate of pass-through reaches unity for the processed foodstuffs, precision instruments, and edible agricultural, livestock, and fishery products. At the other extreme, the long-run pass-through is indistinguishable from zero for pulp, paper, and related products, iron and steel, and non-ferrous metals. It is noted that, depending on how exporters would adjust their product prices, the long-run ERPT can be larger or smaller than the short-run counterpart. If price rigidity exists primarily in the producers' currency terms, exporters may initially pass a substantial portion of the yen's depreciation effect to the importers. However, they may lower the yen prices of their products over time so as not to lose their market shares to the Japanese competitors. Under such circumstances, the degree of ERPT declines to make the long-run coefficient smaller than the short run. On the other hand, exporting firms may initially find it in their interest not to immediately adjust yen prices fully in response to exchange rate changes. In this case, prices tend to be rigid in consumers' currency terms. Instead, they may decide to alter the yen prices to shift more of the depreciation effect to consumers in phases.

Constraining the data to the post-Asian-crisis-sample rarely affects the significance of the pass-through estimates. On the other hand, the sizes of the coefficients are affected to various degrees as seen in the last two columns of Table 4. To assess the extent of an overall inflationary effect, we proceed to calculate the weighted sum of the pass-through coefficients using the by-industry weights listed in 
Panel B of Table A.1 in the appendix. The results are displayed in Panel B of Table 5. For 1995:1-2001:12, the inflationary effects are estimated to be around $0.065 \%$ both in the short-run and the long-run. When constrained to the 1997:7-2001:12 sample, however, the long-run effects decline substantially to $0.049 \%$ while the short-run effects remains at the same magnitude.

Unfortunately, due to the data constraints, we are not able to obtain corresponding figures for earlier sample periods. Thus, no direct implications are drawn on the magnitude of decline in the pass-through coefficients. Nevertheless, the by-industry results also suggest that depreciation is only partially transmitted into an inflation pressure. In particular, for the post-Asian crisis we note that both the by-industry estimates in this section and the by-stage-of-use-and-demand estimates in the previous section suggest that a $1 \%$ depreciation eventually translates to only a $0.05 \%$ overall inflation. In other words, to generate a $1 \%$ inflation, the yen needs to depreciate by $20 \%$.

\section{Conclusion}

The prolonged economic malaise has put the Japanese economy in a rather unusual and problematic situation where general prices decline on a continual basis. There is no doubt that the ongoing deflation has been exerting a detrimental effect on the ailing economy. It is, therefore, highly critical that an effective deflation-combating policy is prescribed immediately. In the current policy debate, the yen's depreciation seems to be gaining popularity as a candidate for an effective deflation-taming tool. Aside from whether or not the BOJ can drive the exchange rate in a particular direction, however, the idea of fighting deflation by depreciation presupposes that exporters to 
Japan shift most of the effects of depreciation to the Japanese importers and consumers. While the assumption of complete pass-through is routinely adopted by traditional open economy models, its empirical validity remains controversial. This is particularly so for Japan today where foreign exporters observe a continual decline in the product prices of the domestic competitors. As Taylor (2000) argues, the degree of ERPT may depend not only on the microeconomic factors, but also macroeconomic factors such as the domestic inflation environment.

In this paper, we have estimated the degrees of pass-through to the Japanese imports over alternative sample periods using two sets of disaggregated price indexes. Using these pass-through estimates, we then calculated how much of a general inflation the yen's depreciation generates via import inflation. The sub-sample estimates suggest that in many product categories ERPT has declined in recent periods consistently with Taylor's (2000) conjecture. Our calculation further confirms a reduction in the magnitude of the overall wholesale inflation attained by the yen's depreciation.

The findings provide some cautionary notes regarding the expected effectiveness of the yen's depreciation in fighting the Japanese deflation. Suppose that the BOJ can induce the yen's effective depreciation by $10 \%$. In the early 1980s, this would have created overall wholesale inflation by the rate of $0.92 \%$ in the long run. However, our estimates for the most recent period suggest that the same $10 \%$ depreciation is expected to lift the wholesale price only by $0.50-0.56 \%$. These changes are well visualized by Figure 3 that describes how the inflation persistence and the effects of depreciation have been shifting. In short, the yen's depreciation is not as effective as it was in earlier periods in creating an inflationary pressure. Clearly, this conclusion by itself does not constitute either thorough refutation or endorsement of a 
particular policy prescription. Rather, it is meant to provide some useful information to enhance our understanding of this critical issue.

In documenting the recent Japanese experience, this study also serves as a unique evaluation of the intriguing proposition Taylor (2000) put forth on the relationship between degrees of pass-through and inflation environment. In that sense, the findings of the current study are meant also to help illuminate a larger picture of price behavior in open economies in general.

Meanwhile, we also recognize the limitations of the current analysis. The sub-sample comparison of ERPT is based on the price indexes that are only crudely disaggregated. Although we supplement it by using the industry data, it is desirable to examine the import price movements over the long horizon with more finely disaggregated data. Also, it will be informative to study the responses of the consumer prices to exchange rate changes, in addition to those of the wholesale prices. These avenues may be pursued as a future extension when the present data limitations are removed. 


\section{References:}

Campa, José Manuel and Linda S. Goldberg. 2002. “Exchange rate pass-through into import prices: A macro or micro phenomenon?” NBER Working Paper 8934.

Choudhri, Ehsan U. and Daila S. Hakura. 2001. "Exchange rate pass-through to domestic prices: Does the inflationary environment matter?” IMF Working Paper WP/01/194.

Dornbusch, Rudiger. 1987. “Exchange rate and prices.” American Economic Review 77: 93-106.

Feenstra, Robert C. 1989. "Symmetric pass-through of tariffs and exchange rates under imperfect competition: An empirical test.” Journal of International Economics 27: 25-45.

Gagnon, Joseph E. and Jane Ihrig. 2001. “Monetary policy and exchange rate pass-through.” Board of Governors of the Federal Reserve System, International Finance Discussion Paper No. 704.

Gagnon, Joseph E. and Michael M. Knetter. 1995. “Markup adjustment and exchange rate fluctuations: Evidence from panel data on automobiles and total manufacturing.” Journal of International Money and Finance 14: 289-310.

Giovannini, Alberto. 1988. "Exchange rates and traded goods prices.” Journal of International Economics 24: 45-68.

Goldberg, Pinelopi Koujianou and Michael M. Knetter. 1997. "Goods prices and exchange rates: What have we learned?” Journal of Economic Literature 35: 1243-1272.

Hooper, Peter and Catherine Mann. 1989. "Exchange rate pass-through in the 1980s: The case of U.S. imports of manufacturing.” Brookings Papers on Economic Activity 1: 297-337.

Marston, Richard C. 1990. "Pricing to market in Japanese manufacturing." Journal of International Economics 29: 217-236.

McCarthy, Jonathan. 1999. "Pass-through of exchange rates and import prices to domestic inflation in some industrialized countries.” Federal Reserve Bank of New York, New York.

Ohno, Kenichi. 1989. "Export pricing behavior of manufacturing: A U.S.-Japan comparison.” IMF Staff Papers 36: 550-579.

Otani, Akira, Shigenori Shiratsuka, and Toyoichiro Shirota. 2003. "The decline in the Exchange Rate Pass-Through: Evidence from Japanese Import Prices.” Monetary and Economics Studies 21: 53-81.

Sazanami, Yoko, Fukunari Kimura and Hiroki Kawai. 1997. "Sectoral price movements under the yen appreciation.” Journal of the Japanese and International Economics 11: 611-641. 
Svensson, Lars E. O. 2003. "Escaping from a liquidity trap and deflation: The foolproof way and others.” Journal of Economic Perspectives, forthcoming.

Taylor, John B. 2000. "Low inflation, pass-through and the pricing power of firms.” European Economic Review 44: 1389-1408.

Yang, Jiawen. 1997. "Exchange rate pass-through in U.S. manufacturing industries.” Review of Economics and Statistics 79: 95-104. 
Table 1. Descriptive statistics

\begin{tabular}{cllll}
\hline Sample period & Mean & Variance & $\begin{array}{l}\text { Coefficient } \\
\text { of variation }\end{array}$ & Persistence \\
\hline A. Wholesale inflation & & & & \\
1973:4-2001:12 & 0.135 & 0.639 & 5.904 & 2.690 \\
1973:4-1979:12 & 0.702 & 1.468 & 1.725 & 3.796 \\
1980:1-1984:12 & 0.163 & 0.539 & 4.483 & 1.083 \\
1985:1-1989:12 & -0.185 & 0.309 & 2.993 & 1.381 \\
1990:1-1994:12 & -0.072 & 0.062 & 3.432 & 0.804 \\
1995:1-2001:12 & -0.053 & 0.129 & 6.762 & 0.321 \\
1997:7-2001:12 & -0.092 & 0.100 & 3.450 & 0.501 \\
B. Exchange rate changes & & & & \\
1973:4-2001:12 & -0.325 & 6.073 & 7.562 & 0.631 \\
1973:4-1979:12 & -0.114 & 4.584 & 18.732 & 0.731 \\
1980:1-1984:12 & -0.374 & 5.764 & 6.419 & 0.499 \\
1985:1-1989:12 & -0.711 & 6.667 & 3.629 & 0.633 \\
1990:1-1994:12 & -0.644 & 4.862 & 3.419 & 0.431 \\
1995:1-2001:12 & 0.007 & 8.123 & 369.635 & 0.692 \\
1997:7-2001:12 & -0.188 & 7.325 & 14.352 & 0.585 \\
\hline
\end{tabular}

Notes: Panels A and B contain the descriptive statistics for the first difference series of the logged wholesale price index and the logged nominal effective exchange rate (both multiplied by 100), respectively. The exchange rate is measured in units of yen per foreign currency so that negative entries indicate appreciation of the yen. The persistence is measured by half-life estimates in months using the first order autoregressive models. 
Table 2. Short-run pass-through estimates

\begin{tabular}{llllllll}
\hline & $\begin{array}{l}\text { Full } \\
\text { sample }\end{array}$ & $1973: 3-$ & $1980: 1-$ & $1985: 1-$ & $1990: 1-$ & $1995: 1-$ & $1997: 7-$ \\
& $1979: 12$ & $1984: 12$ & $1989: 12$ & $1994: 12$ & $2001: 12$ & $2001: 12$ \\
\hline $\begin{array}{l}\text { A. Raw materials } \\
\text { Raw material } \\
\text { for }\end{array}$ & $0.630^{* *}$ & $0.586^{* *}$ & $0.535^{* *}$ & $0.582^{* *}$ & $0.473^{* *}$ & $0.602^{*}$ & 0.425 \\
$\begin{array}{l}\text { processing } \\
\text { Construction } \\
\text { materials }\end{array}$ & $(0.048)$ & $(0.084)$ & $(0.083)$ & $(0.163)$ & $(0.118)$ & $(0.257)$ & $(0.260)$ \\
& $0.270^{* *}$ & n.a. & $0.990^{* *}$, a & $0.363^{* *}$ & -0.229 & $0.236^{* *}$ & $0.261^{* *}$ \\
Fuel & $(0.069)$ & & $(0.154)$ & $(0.114)$ & $(0.288)$ & $(0.073)$ & $(0.091)$ \\
& $0.676^{* *}$ & n.a. & $0.626^{* *}$ & $0.561^{* *}$ & $0.580^{* *}$ & $0.817^{* *}$, a & $0.689^{* *}$, a \\
& $(0.066)$ & & $(0.086)$ & $(0.135)$ & $(0.128)$ & $(0.146)$ & $(0.229)$
\end{tabular}

\section{B. Intermediate materials}

\begin{tabular}{|c|c|c|c|c|c|c|c|}
\hline $\begin{array}{l}\text { Semi-finished } \\
\text { goods }\end{array}$ & $\begin{array}{l}0.529 * * \\
(0.035)\end{array}$ & $\begin{array}{l}0.476 * * \\
(0.116)\end{array}$ & $\begin{array}{l}0.422 * * \\
(0.113)\end{array}$ & $\begin{array}{l}0.437 * * \\
(0.065)\end{array}$ & $\begin{array}{l}0.753 * * \\
(0.079)\end{array}$ & $\begin{array}{l}0.573 * * \\
(0.042)\end{array}$ & $\begin{array}{l}0.552 * * \\
(0.056)\end{array}$ \\
\hline $\begin{array}{l}\text { Construction } \\
\text { materials }\end{array}$ & $\begin{array}{l}0.633^{* *} \\
(0.059)\end{array}$ & $\begin{array}{l}0.219 \\
(0.190)\end{array}$ & $\begin{array}{l}0.832^{*}, \text { a } \\
(0.189)\end{array}$ & $\begin{array}{l}0.916^{* *}, \mathrm{a} \\
(0.176)\end{array}$ & $\begin{array}{l}0.537^{* *} \\
(0.121)\end{array}$ & $\begin{array}{l}0.549 * * \\
(0.078)\end{array}$ & $\begin{array}{l}0.554 * * \\
(0.081)\end{array}$ \\
\hline $\begin{array}{l}\text { Fuel and } \\
\text { energy }\end{array}$ & $\begin{array}{l}0.348^{* *} \\
(0.089)\end{array}$ & $\begin{array}{l}0.277 \\
(0.119)\end{array}$ & $\begin{array}{l}0.306 * \\
(0.133)\end{array}$ & $\begin{array}{l}0.502 * \\
(0.203)\end{array}$ & $\begin{array}{l}0.191 \\
(0.272)\end{array}$ & $\begin{array}{l}0.292 \\
(0.225)\end{array}$ & $\begin{array}{l}-0.069 \\
(0.368)\end{array}$ \\
\hline $\begin{array}{l}\text { Other } \\
\text { intermediate } \\
\text { materials }\end{array}$ & $\begin{array}{l}0.492 * * \\
(0.037)\end{array}$ & n.a. & $\begin{array}{l}0.081 \\
(0.089)\end{array}$ & $\begin{array}{l}0.544 * * \\
(0.080)\end{array}$ & $\begin{array}{l}0.898 * *, a \\
(0.071)\end{array}$ & $\begin{array}{l}0.475^{* *} \\
(0.095)\end{array}$ & $\begin{array}{l}0.355^{* *} \\
(0.118)\end{array}$ \\
\hline \multicolumn{8}{|c|}{ C. Final goods } \\
\hline Capital goods & $\begin{array}{l}0.409 * * \\
(0.030)\end{array}$ & $\begin{array}{l}0.101 \\
(0.082)\end{array}$ & $\begin{array}{l}0.355^{* *} \\
(0.094)\end{array}$ & $\begin{array}{l}0.524^{* *} \\
(0.098)\end{array}$ & $\begin{array}{l}0.433^{* *} \\
(0.056)\end{array}$ & $\begin{array}{l}0.551^{* *} \\
(0.045)\end{array}$ & $\begin{array}{l}0.618 * * \\
(0.050)\end{array}$ \\
\hline $\begin{array}{l}\text { Consumer } \\
\text { durable } \\
\text { goods }\end{array}$ & $\begin{array}{l}0.390 * * \\
(0.034)\end{array}$ & $\begin{array}{l}0.094 \\
(0.064)\end{array}$ & $\begin{array}{l}0.183 \\
(0.134)\end{array}$ & $\begin{array}{l}0.279 * * \\
(0.082)\end{array}$ & $\begin{array}{l}0.707 * * \\
(0.084)\end{array}$ & $\begin{array}{l}0.488 * * \\
(0.033)\end{array}$ & $\begin{array}{l}0.532 * * \\
(0.051)\end{array}$ \\
\hline $\begin{array}{l}\text { Consumer } \\
\text { non-durable } \\
\text { goods }\end{array}$ & $\begin{array}{l}0.432 * * \\
(0.027)\end{array}$ & $\begin{array}{l}0.409 * * \\
(0.092)\end{array}$ & $\begin{array}{l}0.418^{* *} \\
(0.057)\end{array}$ & $\begin{array}{l}0.545^{* *} \\
(0.068)\end{array}$ & $\begin{array}{l}0.303^{* *} \\
(0.054)\end{array}$ & $\begin{array}{l}0.498^{* *} \\
(0.040)\end{array}$ & $\begin{array}{l}0.464 * * \\
(0.063)\end{array}$ \\
\hline
\end{tabular}


Table 3. Long-run pass-through estimates

\begin{tabular}{|c|c|c|c|c|c|c|c|}
\hline & $\begin{array}{l}\text { Full } \\
\text { sample }\end{array}$ & $\begin{array}{l}1973: 3- \\
\text { 1979:12 }\end{array}$ & $\begin{array}{l}1980: 1- \\
1984: 12 \\
\end{array}$ & $\begin{array}{l}1985: 1- \\
\text { 1989:12 }\end{array}$ & $\begin{array}{l}1990: 1- \\
1994: 12\end{array}$ & $\begin{array}{l}1995: 1- \\
\text { 2001:12 }\end{array}$ & $\begin{array}{l}1997: 7 \\
2001: 12\end{array}$ \\
\hline \multicolumn{8}{|c|}{ A. Raw materials } \\
\hline $\begin{array}{l}\text { Raw material } \\
\text { for } \\
\text { processing }\end{array}$ & $\begin{array}{l}0.938^{* *}, \mathrm{a} \\
(0.111)\end{array}$ & $\begin{array}{l}1.128^{* *}, \mathrm{a} \\
(0.154)\end{array}$ & $\begin{array}{l}0.932 * *, a \\
(0.143)\end{array}$ & $\begin{array}{l}1.053^{* *}, \mathrm{a} \\
(0.354)\end{array}$ & $\begin{array}{l}0.402 \\
(0.288)\end{array}$ & $\begin{array}{l}0.001 \\
(0.552)\end{array}$ & $\begin{array}{l}0.159 \\
(0.415)\end{array}$ \\
\hline $\begin{array}{l}\text { Construction } \\
\text { materials }\end{array}$ & $\begin{array}{l}0.394^{* *} \\
(0.095)\end{array}$ & n.a. & $\begin{array}{l}1.121^{* *, a} \\
(0.175)\end{array}$ & $\begin{array}{l}0.582^{* *} \\
(0.160)\end{array}$ & $\begin{array}{l}-0.213 \\
(0.390)\end{array}$ & $\begin{array}{l}0.419 * * \\
(0.076)\end{array}$ & $\begin{array}{l}0.408^{* *} \\
(0.097)\end{array}$ \\
\hline Fuel & $\begin{array}{l}0.904^{* *}, \mathrm{a} \\
(0.225)\end{array}$ & n.a. & $\begin{array}{l}1.145^{* *}, \mathrm{a} \\
(0.203)\end{array}$ & $\begin{array}{l}0.937^{*}, \text { a } \\
(0.371)\end{array}$ & $\begin{array}{l}-0.050 \\
(0.511)\end{array}$ & $\begin{array}{l}0.679 * \\
(0.326)\end{array}$ & $\begin{array}{l}0.345 \\
(0.397)\end{array}$ \\
\hline
\end{tabular}

\section{B. Intermediate materials}

\begin{tabular}{|c|c|c|c|c|c|c|c|}
\hline $\begin{array}{l}\text { Semi-finished } \\
\text { goods }\end{array}$ & $\begin{array}{l}0.610 * * \\
(0.053)\end{array}$ & $\begin{array}{l}0.842^{* *}, \mathrm{a} \\
(0.186)\end{array}$ & $\begin{array}{l}0.517 * * \\
(0.127)\end{array}$ & $\begin{array}{l}0.401 * * \\
(0.104)\end{array}$ & $\begin{array}{l}0.925^{* *}, \text { a } \\
(0.166)\end{array}$ & $\begin{array}{l}0.593 * * \\
(0.048)\end{array}$ & $\begin{array}{l}0.501 * * \\
(0.062)\end{array}$ \\
\hline $\begin{array}{l}\text { Construction } \\
\text { materials }\end{array}$ & $\begin{array}{l}0.388^{* *} \\
(0.133)\end{array}$ & $\begin{array}{l}0.168 \\
(0.752)\end{array}$ & $\begin{array}{l}0.862^{* *}, \mathrm{a} \\
(0.270)\end{array}$ & $\begin{array}{l}-0.097 \\
(0.413)\end{array}$ & $\begin{array}{l}0.200 \\
(0.503)\end{array}$ & $\begin{array}{l}0.385^{*} \\
(0.183)\end{array}$ & $\begin{array}{l}0.383^{*} \\
(0.182)\end{array}$ \\
\hline $\begin{array}{l}\text { Fuel and } \\
\text { energy }\end{array}$ & $\begin{array}{l}1.296^{* *}, \mathrm{a} \\
(0.374)\end{array}$ & $\begin{array}{l}1.521^{* *}, \mathrm{a} \\
(0.482)\end{array}$ & $\begin{array}{l}0.875^{* *}, \mathrm{a} \\
(0.206)\end{array}$ & $\begin{array}{l}1.624 \\
(1.229)\end{array}$ & $\begin{array}{l}-0.248 \\
(0.630)\end{array}$ & $\begin{array}{l}0.960 \\
(0.493)\end{array}$ & $\begin{array}{l}0.384 \\
(0.921)\end{array}$ \\
\hline $\begin{array}{l}\text { Other } \\
\text { intermediate } \\
\text { materials }\end{array}$ & $\begin{array}{l}0.519 * * \\
(0.052)\end{array}$ & n.a. & $\begin{array}{l}0.021 \\
(0.102)\end{array}$ & $\begin{array}{l}0.565 * * \\
(0.092)\end{array}$ & $\begin{array}{l}1.032^{* *}, \mathrm{a} \\
(0.126)\end{array}$ & $\begin{array}{l}0.448 * * \\
(0.109)\end{array}$ & $\begin{array}{l}0.241 \\
(0.157)\end{array}$ \\
\hline \multicolumn{8}{|c|}{ C. Final goods } \\
\hline Capital goods & $\begin{array}{l}0.655^{* *} \\
(0.056)\end{array}$ & $\begin{array}{l}0.693^{* *}, \mathrm{a} \\
(0.191)\end{array}$ & $\begin{array}{l}0.761^{* *}, \mathrm{a} \\
(0.145)\end{array}$ & $\begin{array}{l}0.772^{* *}, \text { a } \\
(0.187)\end{array}$ & $\begin{array}{l}0.621 * * \\
(0.095)\end{array}$ & $\begin{array}{l}0.598 * * \\
(0.059)\end{array}$ & $\begin{array}{l}0.654^{* *} \\
(0.087)\end{array}$ \\
\hline $\begin{array}{l}\text { Consumer } \\
\text { durable } \\
\text { goods }\end{array}$ & $\begin{array}{l}0.464^{* *} \\
(0.055)\end{array}$ & $\begin{array}{l}0.210^{*} \\
(0.095)\end{array}$ & $\begin{array}{l}0.473 * * \\
(0.140)\end{array}$ & $\begin{array}{l}0.384 * * \\
(0.142)\end{array}$ & $\begin{array}{l}0.660 * * \\
(0.154)\end{array}$ & $\begin{array}{l}0.553 * * \\
(0.045)\end{array}$ & $\begin{array}{l}0.552 * * \\
(0.090)\end{array}$ \\
\hline $\begin{array}{l}\text { Consumer } \\
\text { non-durable } \\
\text { goods }\end{array}$ & $\begin{array}{l}0.650 * * \\
(0.053)\end{array}$ & $\begin{array}{l}0.790^{* *}, \mathrm{a} \\
(0.180)\end{array}$ & $\begin{array}{l}0.696^{* *} \\
(0.107)\end{array}$ & $\begin{array}{l}0.730^{* *}, \mathrm{a} \\
(0.143)\end{array}$ & $\begin{array}{l}0.352^{* *} \\
(0.074)\end{array}$ & $\begin{array}{l}0.641^{* *} \\
(0.064)\end{array}$ & $\begin{array}{l}0.607 * * \\
(0.096)\end{array}$ \\
\hline
\end{tabular}


Table 4. Pass-through estimates by industry

\begin{tabular}{|c|c|c|c|c|}
\hline & \multicolumn{2}{|l|}{ 1995:1-2001:12 } & \multicolumn{2}{|c|}{ 1997:7-2001:12 } \\
\hline & Short-run & Long-run & Short-run & Long-run \\
\hline \multicolumn{5}{|l|}{ A. Manufacturing } \\
\hline \multirow[t]{2}{*}{ Processed foodstuffs } & $0.607 * *$ & $0.846^{* *}$, a & $0.671 * *$ & $0.927^{* *}$, a \\
\hline & $(0.056)$ & $(0.150)$ & $(0.067)$ & $(0.177)$ \\
\hline \multirow[t]{2}{*}{ Textile products } & $0.487 * *$ & $0.551^{* *}$ & $0.463 * *$ & $0.533 * *$ \\
\hline & $(0.052)$ & $(0.056)$ & $(0.076)$ & $(0.078)$ \\
\hline \multirow[t]{2}{*}{ Lumber \& wood products } & $0.738 * *$ & $0.595 * *$ & $0.791^{* *}$ & $0.602 * *$ \\
\hline & $(0.072)$ & $(0.097)$ & $(0.078)$ & $(0.103)$ \\
\hline \multirow{2}{*}{$\begin{array}{l}\text { Pulp, paper \& related } \\
\text { products }\end{array}$} & $0.442 * *$ & -0.432 & $0.541^{* *}$ & 0.066 \\
\hline & $(0.131)$ & $(0.308)$ & $(0.121)$ & $(0.237)$ \\
\hline \multirow[t]{2}{*}{ Chemicals } & $0.365 * *$ & $0.465 * *$ & $0.402 * *$ & $0.447 * *$ \\
\hline & $(0.057)$ & $(0.069)$ & $(0.060)$ & $(0.099)$ \\
\hline \multirow[t]{2}{*}{ Plastic products } & $0.796 * *$ & $0.742 * *$ & $0.860^{* *}$, a & $0.685^{* *}$, a \\
\hline & $(0.098)$ & $(0.100)$ & $(0.124)$ & $(0.153)$ \\
\hline \multirow[t]{2}{*}{ Petroleum \& coal products } & $0.544^{* *}$ & 0.291 & 0.242 & 0.004 \\
\hline & $(0.202)$ & $(0.269)$ & $(0.233)$ & $(0.334)$ \\
\hline \multirow{2}{*}{$\begin{array}{l}\text { Ceramic, stone \& clay } \\
\text { products }\end{array}$} & $0.597 * *$ & $0.713^{* *}$ & $0.518 * *$ & $0.704^{* *}$ \\
\hline & $(0.048)$ & $(0.072)$ & $(0.069)$ & $(0.082)$ \\
\hline \multirow[t]{2}{*}{ Iron \& steel } & $0.172^{* *}$ & 0.117 & $0.296 * *$ & $0.293 *$ \\
\hline & $(0.064)$ & (0.105) & (0.077) & (0.137) \\
\hline \multirow[t]{2}{*}{ Non-ferrous metals } & $0.717 * *, \mathrm{a}$ & 0.268 & $0.942^{* *}$, a & 0.287 \\
\hline & $(0.145)$ & $(0.203)$ & $(0.229)$ & $(0.311)$ \\
\hline \multirow[t]{2}{*}{ Metal products } & $0.478 * *$ & $0.493 * *$ & $0.372 * *$ & $0.454^{* *}$ \\
\hline & $(0.063)$ & $(0.101)$ & $(0.113)$ & $(0.118)$ \\
\hline \multirow[t]{2}{*}{ General machinery } & $0.752 * *$ & $0.789 * *$ & $0.783 * *$ & $0.823^{* *}$, a \\
\hline & $(0.056)$ & (0.078) & $(0.049)$ & $(0.082)$ \\
\hline \multirow[t]{2}{*}{ Electrical machinery } & $0.598 * *$ & $0.629 * *$ & $0.687 * *$ & $0.741^{* *}$ \\
\hline & $(0.041)$ & $(0.050)$ & $(0.056)$ & $(0.091)$ \\
\hline \multirow[t]{2}{*}{ Transportation equipment } & $0.473 * *$ & $0.525 * *$ & $0.463 * *$ & $0.487 * *$ \\
\hline & $(0.040)$ & $(0.052)$ & $(0.047)$ & $(0.057)$ \\
\hline \multirow[t]{2}{*}{ Precision instruments } & $0.683^{* *}$ & $0.853^{* *}$, a & $0.690 * *$ & $0.811^{* *}$, a \\
\hline & $(0.051)$ & $(0.088)$ & $(0.072)$ & $(0.116)$ \\
\hline Other manufacturing & $0.803^{* *, a}$ & $1.178^{*}, \mathrm{a}$ & $0.714^{* *}$ & $0.817^{* *}, \mathrm{a}$ \\
\hline industry products & $(0.125)$ & $(0.542)$ & $(0.065)$ & $(0.109)$ \\
\hline \multicolumn{5}{|c|}{ B. Agricultural, forestry \& fishery products } \\
\hline Edible agricultural, livestock & $0.614^{* *}$ & $0.894^{* *}$, a & $0.657 * *$ & $0.925^{* *}$, a \\
\hline \multirow{2}{*}{$\begin{array}{l}\text { \& fishery products } \\
\text { Inedible agricultural \& }\end{array}$} & $(0.081)$ & $(0.131)$ & $(0.100)$ & $(0.158)$ \\
\hline & $0.920 * *$, a & $0.876^{* *}$, a & $0.936^{* *}$, a & $0.805^{* *}$, a \\
\hline $\begin{array}{l}\text { Inedible agricultural \& } \\
\text { forestry products }\end{array}$ & $(0.074)$ & (0.138) & (0.098) & (0.139) \\
\hline \multicolumn{5}{|l|}{ C. Mining product } \\
\hline Forestry products & $0.925 * *$, a & $0.998 * *$, a & $0.868 * *$, a & $0.906^{*}, \mathrm{a}$ \\
\hline & $(0.144)$ & $(0.356)$ & $(0.266)$ & $(0.489)$ \\
\hline D. Scrap \& Waste & & & & \\
\hline Scrap \& Waste & $0.568 * *$ & 0.270 & $0.610 * *$ & $0.567 * *$ \\
\hline & $(0.100)$ & $(0.151)$ & $(0.101)$ & $(0.155)$ \\
\hline
\end{tabular}

Notes: “**” and “*” indicate statistical significance at the $1 \%$ and $5 \%$ levels, respectively. For the statistically significant coefficients, "al” denotes acceptance of the null hypothesis of a full pass-through (i.e. the estimated pass-through coefficient being equal to one) at the $5 \%$ level. 
Table 5. Estimated effects of 1\% depreciation on the overall wholesale price inflation

\begin{tabular}{ccc}
\hline & Short-run & Long-run \\
\hline A. By-stage-of-use calculation & & \\
Full sample & 0.0668 & 0.0785 \\
1980:1-1984:12 & 0.0628 & 0.0918 \\
1985:1-1989:12 & 0.0738 & 0.0646 \\
1990:1-1994:12 & 0.0672 & 0.0474 \\
1995:1-2001:12 & 0.0691 & 0.0559 \\
1997:7-2001:12 & 0.0560 & 0.0503 \\
1995:1-2001:12 & & \\
1997:7-2001:12 & 0.0653 & 0.0664 \\
\hline
\end{tabular}

Notes: The entries denote estimated overall wholesale price inflation in percentage term resulting from one percent depreciation of the yen. The exchange rate pass-through coefficient estimates are used for the calculation while assuming no change in domestic product prices. 


\section{The Appendix}

Table A.1 Product categories and assigned weights in the overall wholesale price index

\begin{tabular}{|c|c|c|}
\hline & Domestic products & Imports \\
\hline \multicolumn{3}{|l|}{ A. By stages of use and demand } \\
\hline Raw Materials & 20.4 & 21.75 \\
\hline Raw material for processing & 12.3 & 18.28 \\
\hline Construction materials & 4.22 & 0.11 \\
\hline Fuel & 0.33 & 3.36 \\
\hline Other raw materials & 3.55 & 0 \\
\hline Intermediate materials & 405.74 & 30.28 \\
\hline Semi-finished goods & 242.32 & 25.42 \\
\hline Construction materials & 68.81 & 25.42 \\
\hline Fuel and energy & 42.77 & 1.06 \\
\hline Other intermediate materials & 51.84 & 0.51 \\
\hline Finished goods & 366.72 & 35.77 \\
\hline Capital goods & 129.35 & 10.42 \\
\hline Consumer durable goods & 69.54 & 7.62 \\
\hline Consumer non-durable goods & 167.83 & 17.72 \\
\hline Total & 792.86 & 87.79 \\
\hline \multicolumn{3}{|l|}{ B. By industry } \\
\hline Manufacturing & 725.42 & 63.68 \\
\hline Processed foodstuffs & 87.97 & 4.22 \\
\hline Textile products & 22.05 & 7.3 \\
\hline Lumber \& wood products & 12.96 & 3.06 \\
\hline Pulp, paper \& related products & 25.3 & 1.48 \\
\hline Chemicals & 61.77 & 6.61 \\
\hline Plastic products & 29.21 & 0.26 \\
\hline Petroleum \& coal products & 22.51 & 2.78 \\
\hline Ceramic, stone \& clay products & 27.92 & 0.91 \\
\hline Iron \& steel & 34.33 & 1.64 \\
\hline Non-ferrous metals & 16.71 & 4.83 \\
\hline Metal products & 36.32 & 0.86 \\
\hline General machinery & 82.45 & 3.81 \\
\hline Electrical machinery & 122.3 & 14.8 \\
\hline Transportation equipment & 65.07 & 4.32 \\
\hline Precision instruments & 9.05 & 1.88 \\
\hline Other manufacturing industry products & 69.5 & 4.92 \\
\hline Agricultural, forestry \& fishery products & 23.61 & 8.16 \\
\hline Edible agricultural, livestock \& fishery products & 21.7 & 4.67 \\
\hline Inedible agricultural \& forestry products & 1.91 & 3.49 \\
\hline Mining product & 6.97 & 15.53 \\
\hline Forestry products & 6.97 & 15.53 \\
\hline Electric power, gas \& water & 34.62 & 0 \\
\hline Scrap \& Waste & 2.24 & 0.42 \\
\hline Scrap \& Waste & 2.24 & 0.42 \\
\hline Total & 792.86 & 87.79 \\
\hline
\end{tabular}

Source: The Bank of Japan Financial and Economic Data 2002. 
Figure 1. Wholesale price indexes

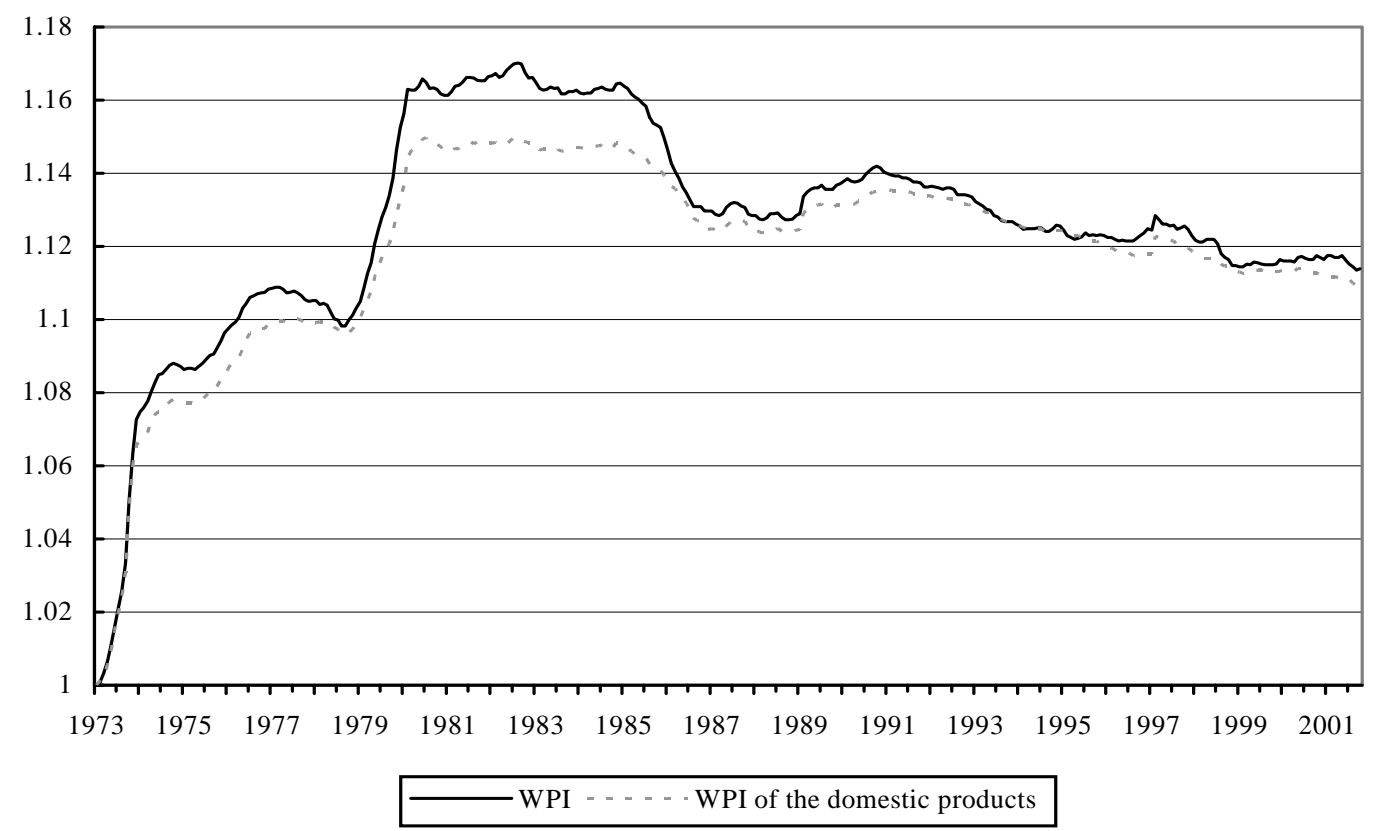

Figure 2. Nominal effective exchnage rate

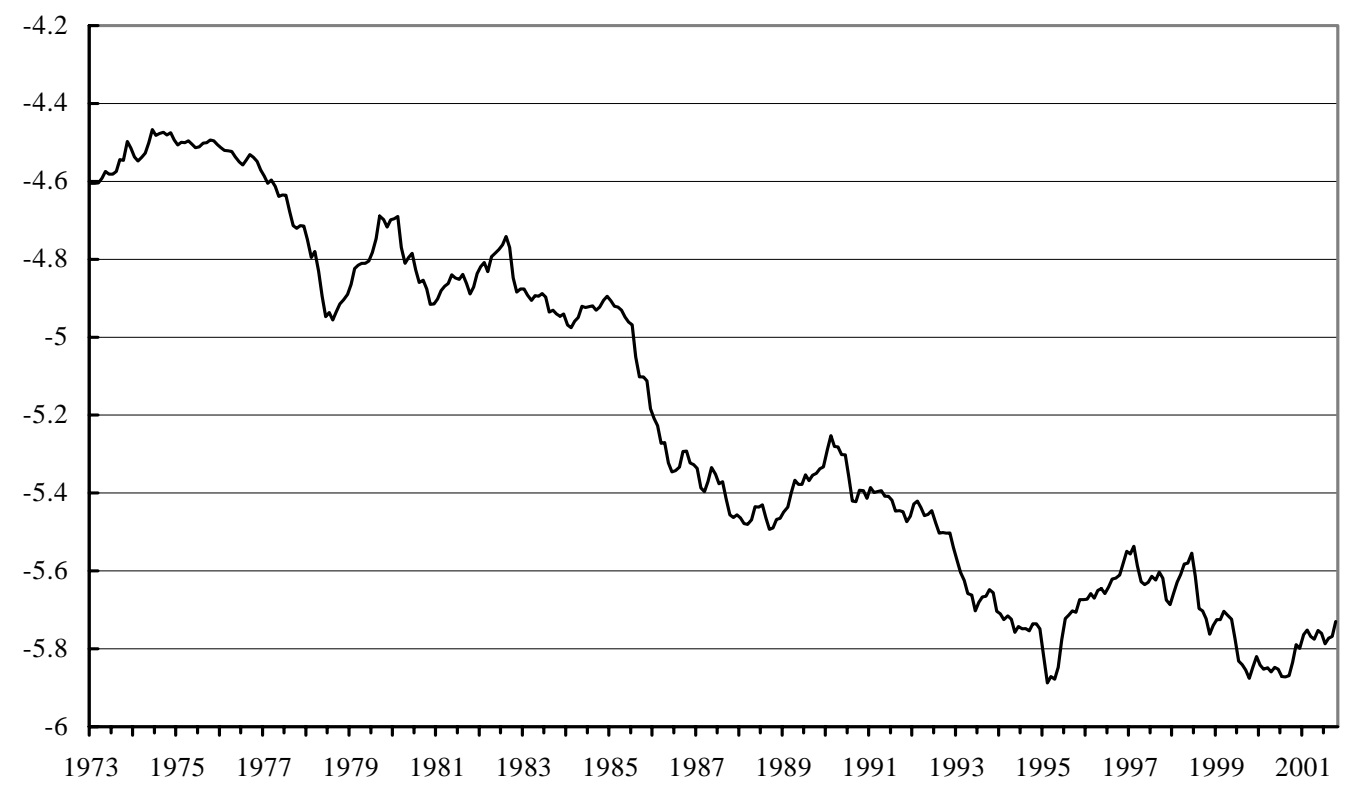

Notes: The overall wholesale price index (WPI) and the WPI for the domestic products in logarithms (normalized to be unity in 1973:3) are plotted in Figure 1.A. Figure 1.B depicts the yen's nominal effective exchange rate in logarithm measured in units of yen per unit of the foreign currency. 
Figure 3. Inflation persistence and effects of depreciation

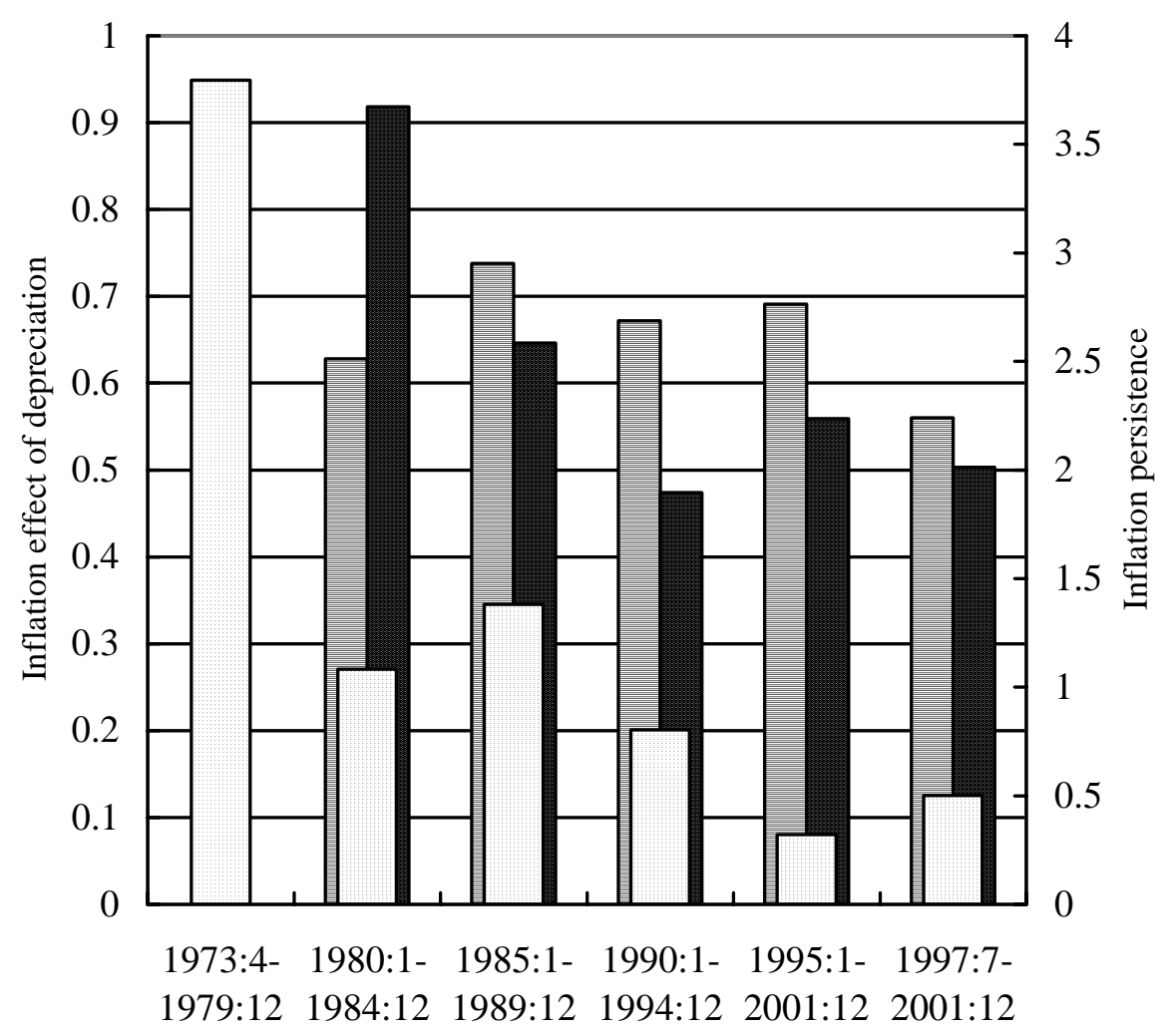

Short-run effect $\square$ Long-run effect $\square$ Inflation persistence

Notes: The short-run and long-run effects are estimated wholesale inflation in \% resulting from a $10 \%$ depreciation. These effects are obtained by using the short-run and long-run pass-through coefficients, respectively, that are estimated from the price data disaggregated by the stage of use and demand. The inflation persistence is measured in terms of half-life of the overall wholesale inflation in months and drawn against the second vertical axis. 